AUThOA8): J.S. Wllson, L.M. Holland, M.S. Halleck, E. Martinez, and G. Saundera

submitieo to. Proceedings of the XIth Internatlonal Congrens on Occupat Lonal Health in the Chemicnl Industry, September 26-29, 1983, Colgary, Cinuda

\title{
DIS 'I.AIMSR
}

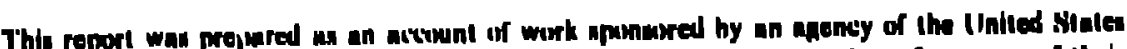

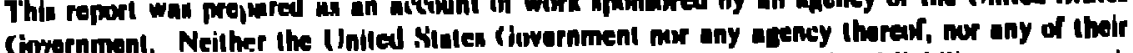
employees, males any warranly, exprens ur I'nplied, or nusumes any lopal liahility or reaponst-

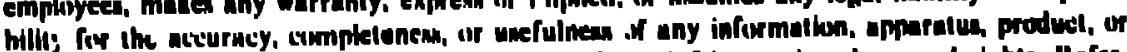

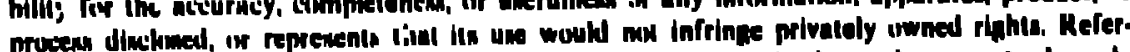

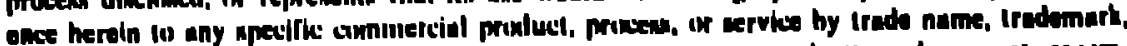

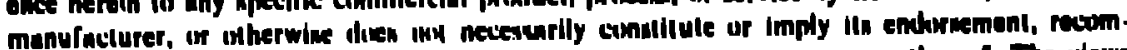

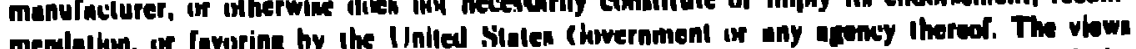

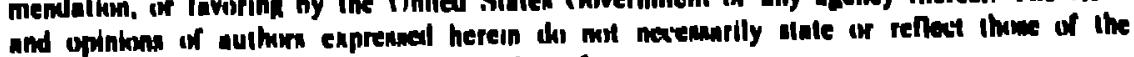

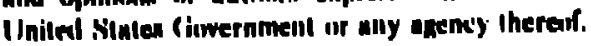

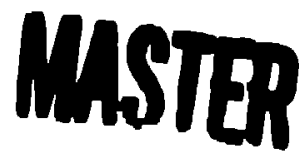

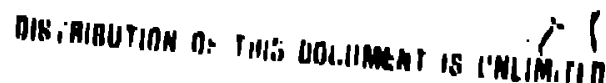

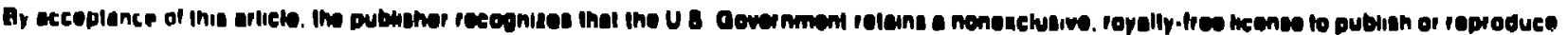

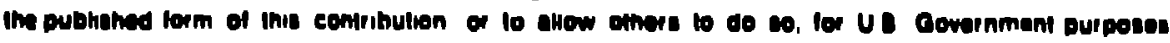

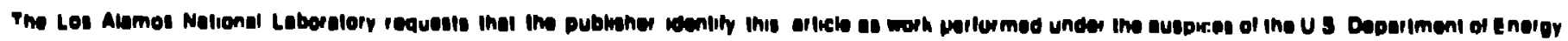

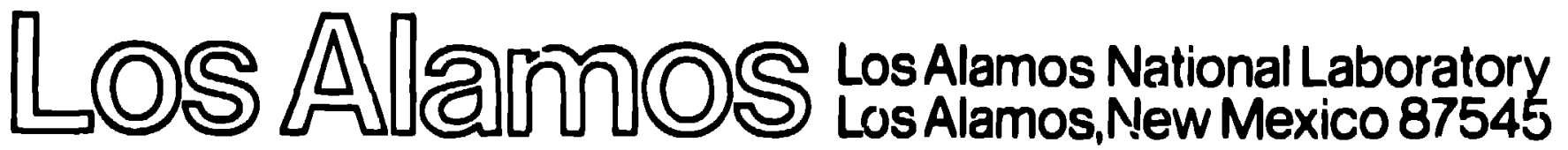


PARTICULATE OIL SHALE INHALATION AND PULMONARY INFLAMMATOKY RESPONSE IN RATS

\author{
J.S. Wilson, ${ }^{1}$ L.M. Holland, ${ }^{1}$ M.S. Halleck, ${ }^{2}$ \\ E. Martinez, ${ }^{1}$ and G.C. Saunder $\mathbf{s}^{1}$ \\ 'Life Sciences Division, Los Alamos National Laboratory \\ Los Alamos. New Mexico 87545 \\ 2Pennsylvania State University, University Park, Pennsylvania 16802
}

\title{
INTRODUCTION
}

011 shale depcsits located in the western United States provide an unexploited source of domestic crude o1l. Development of this resnurce has been IImited by economics; however, recent reduction of recovery costs coupled with the possibility of liquid fuej shortages encourage continued development of improved recovery technologies. Along with technology develupment, a parallel effort to define the potential occupational and environmental hazards associated with extraction of ofl from ofl shale 13 ongoing at the l.1fr Sciences Division of the Los Alamos National Laboratory. The present status of this industry and the prospect that it could expans to rull oupacity present a rilngular opportunity to define hazards which will racilitate industrlal hyglenc and environmental controls as part of the development, growth and expansion of the industry. This study presents one facet of our efforts to define the huzards and to understand the mechandsms that may result from inhalation of the several dusts inherent in the processing of oll shole.

In this study we investigate: 1) the progression of b101081cal response rollowing shale- and quarlz-dust inhalation: 2) recovery following cessation of exposure and 3) the potentlal for permanent Injury. Two endpoints were of primary importance: ribrosds and tumorlgenesis, whlch can occur separately or in 
parallel. Our study concentrated on the events resulting in pulmonary fibrosis. In addition to collecting data at 1, 3, 6 and 12 months of exposure, we included sufficlent animals to harvest samples at several intervals after the exposure endea. Each sacrifice point has three sample elewents: 1) those taken Immediately after termination of exposure; 2) those taken $i$ days after termination of exposure: and 3) those taken 30 days after termination of exposiune.

\section{MATERIALS AND METHODS}

Fenale Fischer-344 rats were exposed to well characterized aerosols of row oll shale or quartz (Minus1l, P1ttsburgh Sand and Glass $C_{0}$. ). Groups of rats were exposed to the aerosols in a nose-only configuration (1). The exposures were oonducted for 6 hisurs on each of 4 days/week for perlods of 1, 3, 6 and 12 months. The masi concentration of shale dist aerosol was $10 \mathrm{mg} / \mathrm{m}^{3}$. Equal numbers of animals were exposec as positive controls for fibrogenesis to an Aerosol of quartz for the same 1-, 3-, 6- and 12-month perlods. The quartz concentration was established at $1 \mathrm{mg} / \mathrm{m}^{3}$, because raw oll shale contains about $10 \%$ quartz, therefore, exposing all groups to approximately equivalent quartz levels. The quartz aeroso! had a mass median aerodynamic diameter (MMAD) of approximately one micron (S.D. $=1.8)$. The MMAD for shale dust was approximately two miorons (S, D. $=1,8$ ), as determined by casiade impactor sampling. To complete the study a group of age-matohid cage controls were maintained in the same animal rooms.

Anlmals were randomily selected for socriflue with four animals from each of the two exposure groups and the sontrol group euihanized by Intraperitoneal injection of pentabarbitol sodfum (2', mg). The lungs were surglcally exposed and the left lung 1solated by ligating the left bronchus. The lobes of the 
right lung were lavaged four times with 5 mL of normal snline and subsequentiy fixed in $10 x$ formalin for histological evaluation. The left lung was frozen for collagen analysis. The oollagen assay has been deseribed (2). Briefly, it involves acid hydrolysis and purification of hydroxy-proline, a building block of collagen, followed by colorimetric quantitation. The lavage fluids were separated Into fluid and cellular components. The fluid portion was frozen $\left(4^{\circ} \mathrm{C}\right)$ and later thawed and assayed for elastase by the Enzyme Labelled Substrate Assay (ELSA) method (3). Total and differential ccil counts were determined for the cellular fracticns. Microscoplc examination of the right lobes was performed on tll lungs.

\section{RESULTS}

We proposed that presence of increased elastase levels in the lavage fluids could be a measure of evolving lung tigsue infury. Decreased elastase levels were observed in the quartz-exposed animals when compared to controls at the 3- and 6-month exposure points (FiB. 1). The shale-exposed er.1mal is had lavage fluid elastase levels higher than those from the quartz-exposed and comparsble to control values at both these points. At 12 months, the shale-treated animals exhibited values signiflcantly higner thain controls, while the values of the quertz-exposed animals compared to controls were not significantly oifferent.

Exfollative cells from the lung have long been used to evaluate responses to Inhaled materials in an effort to predict dysfunction or disease (4). Pulmonary alveolar macrophages (PAM) comprise the majorlty of the oells in lavage fluids. Other constituents are polymorphonuclear cells (PMN), lymphocytes, and eplthelial cells. Two important crlterla for assessing change or response are total oell yleld and the relative numbers of each cell type. 
The average cell yleld Trom control animals was about two million cells at each time polnt over the course of the experiment (Table I). The total cell yield for the shale-treated animals was not signifioantly different from the age-watched controls at any of the sacrifice dates. For the quartz-exposed animals, the harvests at 6 and 12 months were significantly differest, teing elevated to $2.7-2.9$ million vells $(p<.05)$. The volumes retrieved in all cases were oomparable, between 16 and $19 \mathrm{~mL}$. The number of PMN steadily increased with time for both shale- and quartz-t-eated animals with the latter showing the greatest increases. Table I shows the Increasing cell yieids from quartzexposed animals, a decreasing number of PAM and increasing numbers of lymphocyces and PFiN. Numbers of PAM are not significantly different from controls for either shele- or quartz-exposed animals except for the 3-month exposures, at which time PAM are significantly depressed from shale-exposed and controls. All of these observations are for the samples taken from the animals sacrificed imrecilately after cessation of exposure.

Levels of hydroxy-prolinc, a oonstituent of collagen, showed a silall but steady Increase over the course of the experiment in all groups, out there were no signiflcant differences between the cuntrols and the treated animals (F1g. 2). The last collagen data taken for the 12-month exposures sholled a slgniflcant increase in the quartz-exposed group compered to controls. Shaleexposed animals exhiblted increased levels that were not statistically signiricant.

When the animals were allowed a recovery perlod of 7 or 30 days, the changes in PAM and PMN abundance were even more dramatic. Aga1n, at the oarliest sacrifices ( 1 and 3 months) there were no ohanges in relative numbers or PAM or PMN as reflected in the total cell ylelds (F1g. 3). However, at o1x months the total oell yields increased almost exclusively as a result of an 
increase in PMN (FIB. 4); macrophage numbers for both shale and quartz-trerited samples remainei near control levels (Table II). By 12 months of exposure, the total cell ylalds after 7 days recovery were elevated for both groups compared to controls and were even more so at the 30-day recovery poinu. These inrreases are due to elevated numbers of 1 ymphocytes and PMN after 7 days recovery and after 30 days both shale- and quartz-exposed have significant increases in PAM, lymphocytes and PMN. In conjunction with tilis, no significant, lesions were noted microscopically in the shale-exposed animals, but it 6 months severai quartz-exposed animals had pneumonia, granulomas or fibrosis, alone or in combination (F1g. 5). At 12 months of exposure, all the quartz-exposed animals had developed granulomas, while the shale-exposed antmals remained devold of significant lesions (Fig. 6).

\section{DISCUSSION}

Our goal in this endeavor was to define the temporal response of the lung to Inhaled shale dust and to compare these findings with those in animals exposed to a known flbrogenic agent. During the course of the experiment, lavaged cells indlcated inclammatory responses to both shale and quartz, but the responses to quartz were more pronounced. When the animals were allowed a recovery perlod arter treatment, those from the later time points had a greatcr Influx of UMN for beth treated groups. The increase in the number of cells harvested resulted almost exclusively from an increase in PMN and lymphocytes. Both macrophages and PMN contain lysosomal enzymes, Including elastase, a neutral protease wh th specific lytic activity for native soluble collagen and active at neutral $\mathrm{pH}$. Wc assayed the lavage rluids for elastase expecting to find Increases at some time during the colurea of data collection. However. there were no $318 n 1$ flcant differences botween oontrols and treated groups. Ai 
this time it's unclear whether the lack of any specific change was the result of technique insensitivity or actually reflected biological response. Quantification of collagen present 1. the left lung falled to indicate any temporal gradations or differences in effects between groups. It is conceivable that 12 months of exposure was the point at which, under the conditions of this experlment, excess collagen icild become apparent. Analysis of lungs from animals exposed 18 and 24 zonths might reveal differences.

\section{CONCLUSIONS}

In summary, this experimeni indlcates that long-term inhalation of shale dusts by rats elicits a limited inflammatory response in the lung less profound than that observed in animals exposed to equivalent levels of quartz alone. This observation is significant because, while the concentration of quartz used was equivalent to the amount found in the shale. shale contains organic and Inorganic constituents that nay provide a protective effect. Tlie Implications for flbrogen:c disease are two-fold: 1) Inhalation of oll shale dusts appeared to be less detrimental than the inhalation of quartz alone, and 2) there was no apparent synergistic action of cilartz and the complex of organic materials present in shale. Animals exposed to shale dusts falled to develop any significant lung lesions, while ali of the animals exposed to quartz develuped granulamas and some rrank ribrosis. Apparently, it takes more than three months but lesa Lhan six months of continuous cuartz exposure at $1 \mathrm{mg} / \mathrm{m}^{3}$ to elli:lt an Inflammatory response in the lungs, but longer than $s 2 x$ months for a similar responsa in animals exposes to shale, oven though the quartz levels were roughly equivalent. Additionally, the numbers of recruited PAM and PMN are persistent after six months of exposure and even increase then the insult is discontinued. This inorease in cell numbers after discont 
from a macrophage-leukocyte recruitrent inhibition. The release of lytic enzymes rrom PAMs and PMNs into 1 ung parenchyma $1 \mathrm{~s}$ one mechanisn that could explain the presence of flbrosis. Ibwever, we currently have no information about the furctional caponity of these cells. We lintend to investigate this very important aspect of the injury-repair mechaniso in future work. After the 12 months of Inhalation, the fibrogeric action of quartz alone was emphasizet $t y$ the observation of silica-positive granulomas in the quartz-exposed animals wher. no similar lesions were observed in shale-exposed animals.

Autopsy data acquired by Seaton et 브. On Scottish shaile miners demonstrates increased Incidence of both fneumoconiosis and neoplasia following decades of occupational exposure to native shale dusts (5). We also have data from IIfetime, high-conceritration inhalation and intratracheal instillation experiments in which ribiosis and tumors were observed in shale-exposed rats (6). We are continuling our efforts to understand the progression and specific nature of the toxicity of shale dusts as iell as the responses ur spectric cell types involved in disease processes.

\section{REFERENCES}

1. D.M. Smith, L.h.Ortiz, H.F. Archuleta, J.F. Spalding, H.J. Ettınger, M.I. Tillery, and R.C. Thamas. "A Method for Chronic Nose-Only Exposire of Laboratory AnLinals to Inhaled Fibrous Aerusols." In the Proceedings or Inhalation Toxicology and Technology Symposium, Kalamazoo, Michlgan October. 1980 (B.K.J. Leong, Edltor;. Ann Arbor. Ann Arbor Sclence (1982), pp. 89-105.

2. M.S. Halleck, "A Rapid, Sensitive, Microassay for Hydroxy-Proline," Fed. Pro. 41 (Abstracts). 2134 (1982). 
3. G.C. Saunders, 2. Svitra, and A. Martinez, MPrimary Enzyme Quantitation Using Substrates Labeled with a Second Indicator Enzyme. I. Elastase Deterwination Using Peroxidase-Labeled Elastin." Analyt. Biochem. 126. $17.2-130(1982)$.

4. G.W. Hunninhake, J.E. Gadak, O. Kawanam1, V.J. Ferrans, and R.G. Crystal, "Inflamatory and Immune Processes in the Human Lung in Health and Disease: Evaluation by Bronchoalveolar Lavage," Am. J. Path. 97 (1), 149-199 (1979).

5. A. Seaton, D. Lamb, W.R. Brown, G. Sclare, and W.G. Middleton, "Pneumonoconiosis of Shale Miners," Thora, 36, 412-418 (1981)

o. L.M. Holland, M. Gonzales, J.S. Wilson, and M. I. Tillery, "Pulmonary Effects or Shale Dust.s in Experimental Animals." in Health Issues Related to Metal and Nonmetallic Mining (Butterworth Publishers, An Ann Arbor Science Book, 19tj). pp. 485-94. 
Figure 1. Elastase levels ( $\mu g_{i} \mathrm{in}$ ) in lavage fluids from quartz-exposed. shale-exposed, and control animals. There were no signifjcantly different values for either of the treated groups compared to the controls, except for the shale-exposed animals at 12 months. 


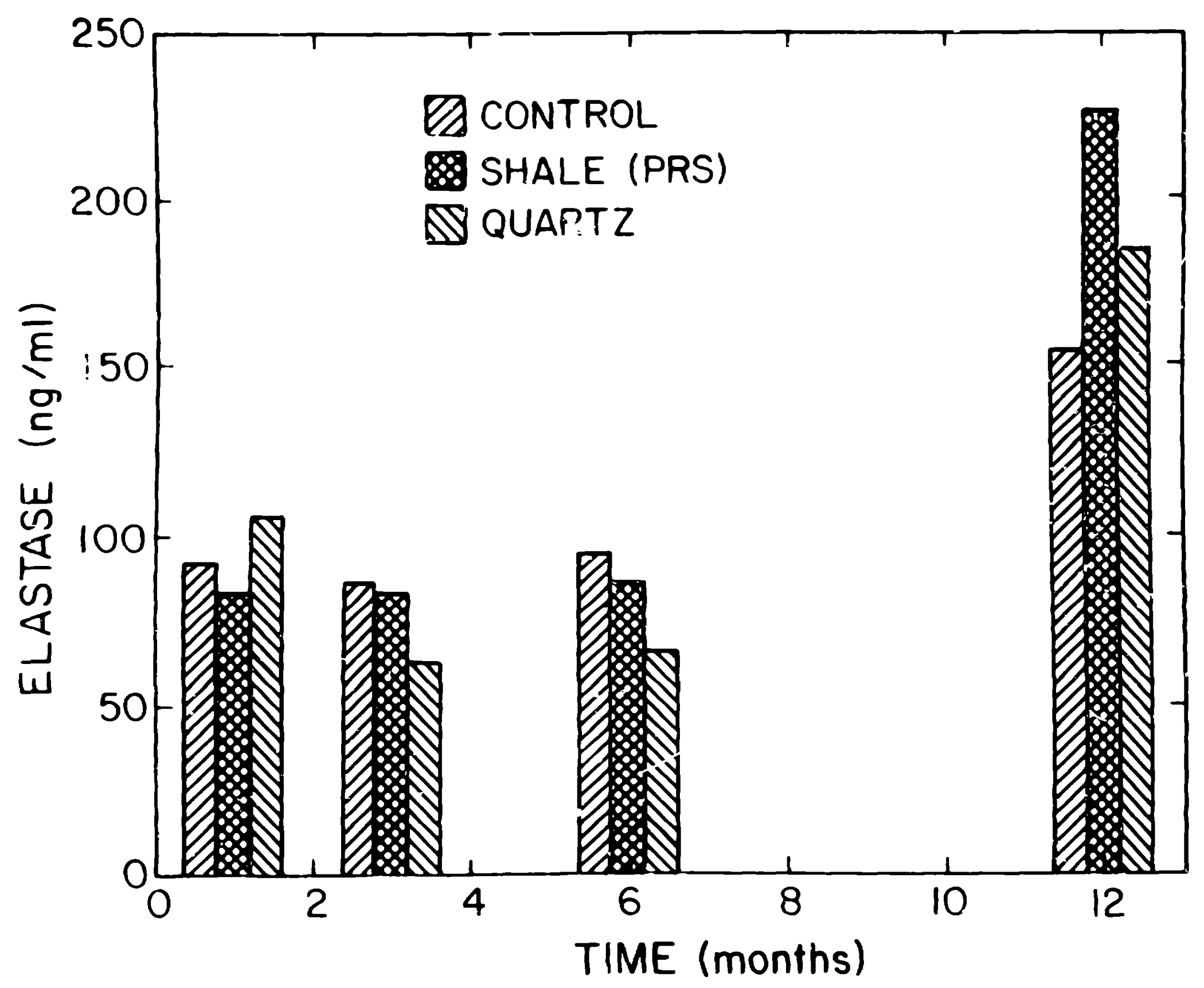


Figure 2. Hydroxy-proline levels in the left lungs of all exposed and control animals. Comparisons at 1, 3, 6, and 12 months of exposure show no significant differences for either of the treated groups versus the controls. 


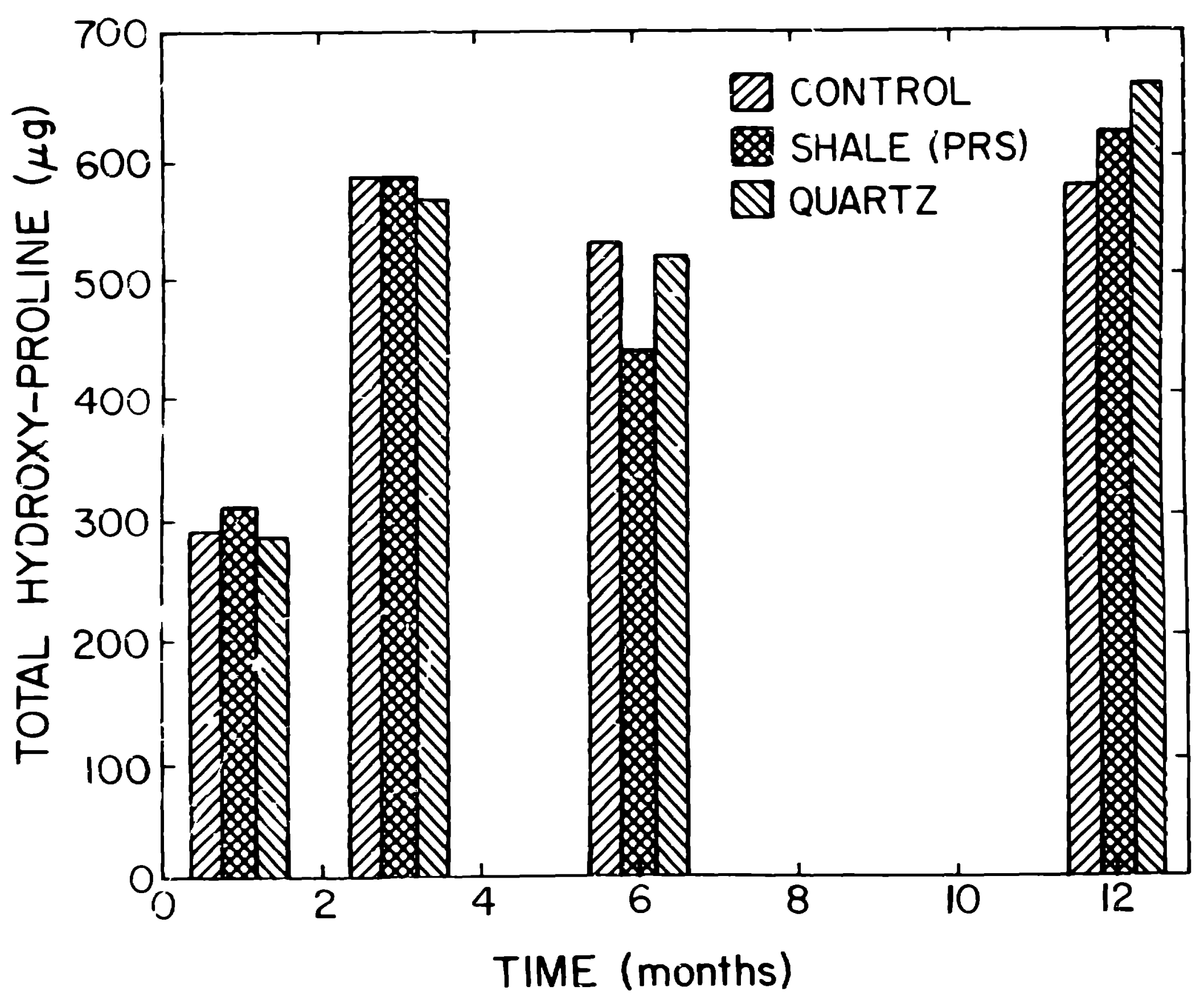


Figure 3. Lavaged cell yields after 1 und 3 months of exposure to quartz ( $\square$ ) or shale $(\Delta)$ along with age-matched controls $(0)$ show no significent differences. At $t=0$, treatment is discontinued and subsequent data points are plotted after recovery periods of 7 and 30 days. 


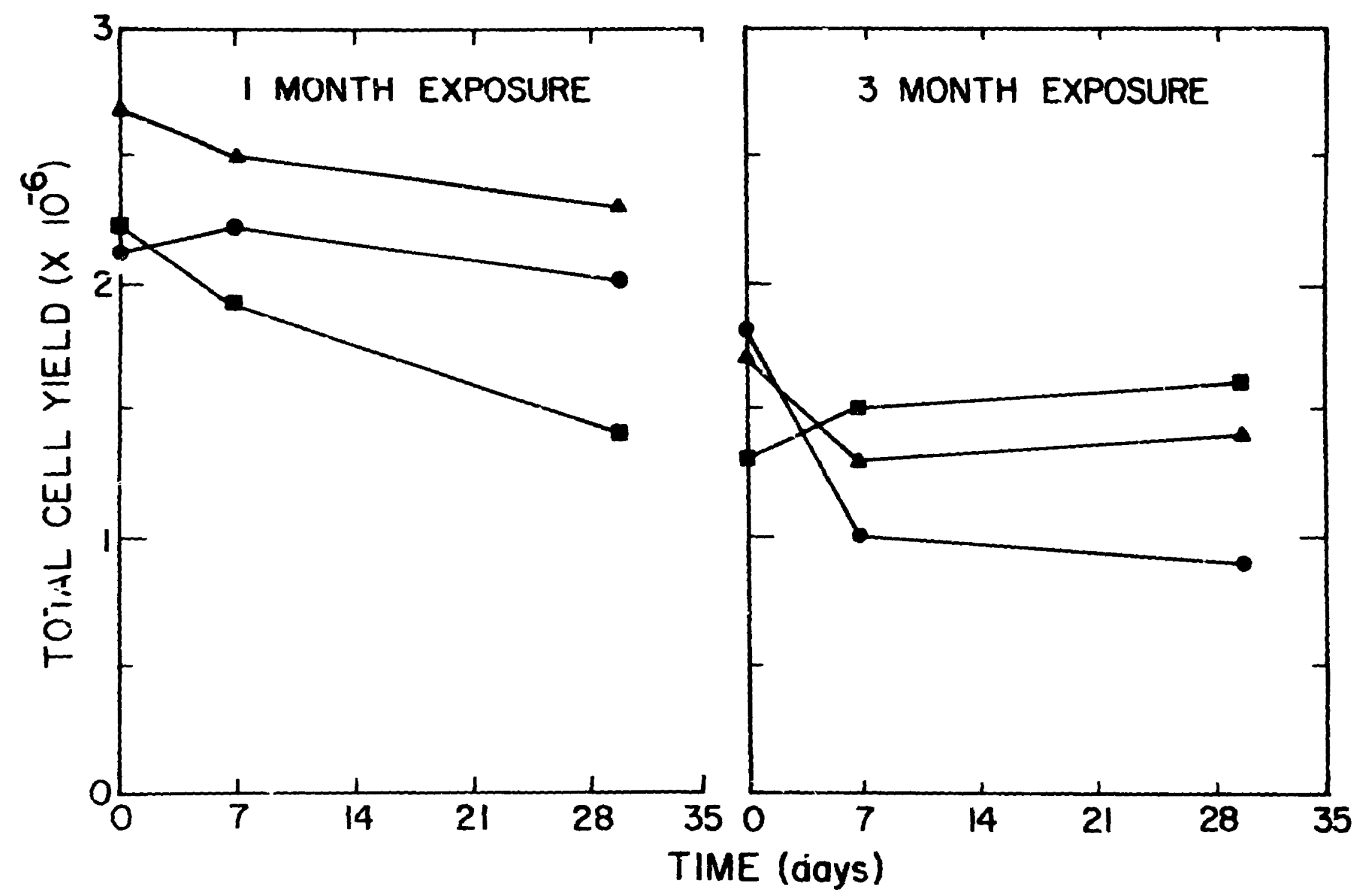


F1gure 4. After 6-month exposure to quartz $(\square)$ or shale $(\Delta)$, the number of PMNs havested from the quartz-exposed, $t=0$, is elevated. Treatment was discontinued and the number of PMN's harjested after 7 and 30 days recovery continued to rise for the quartz-treated animals. Controls $(0)$ show ne ohanges. 


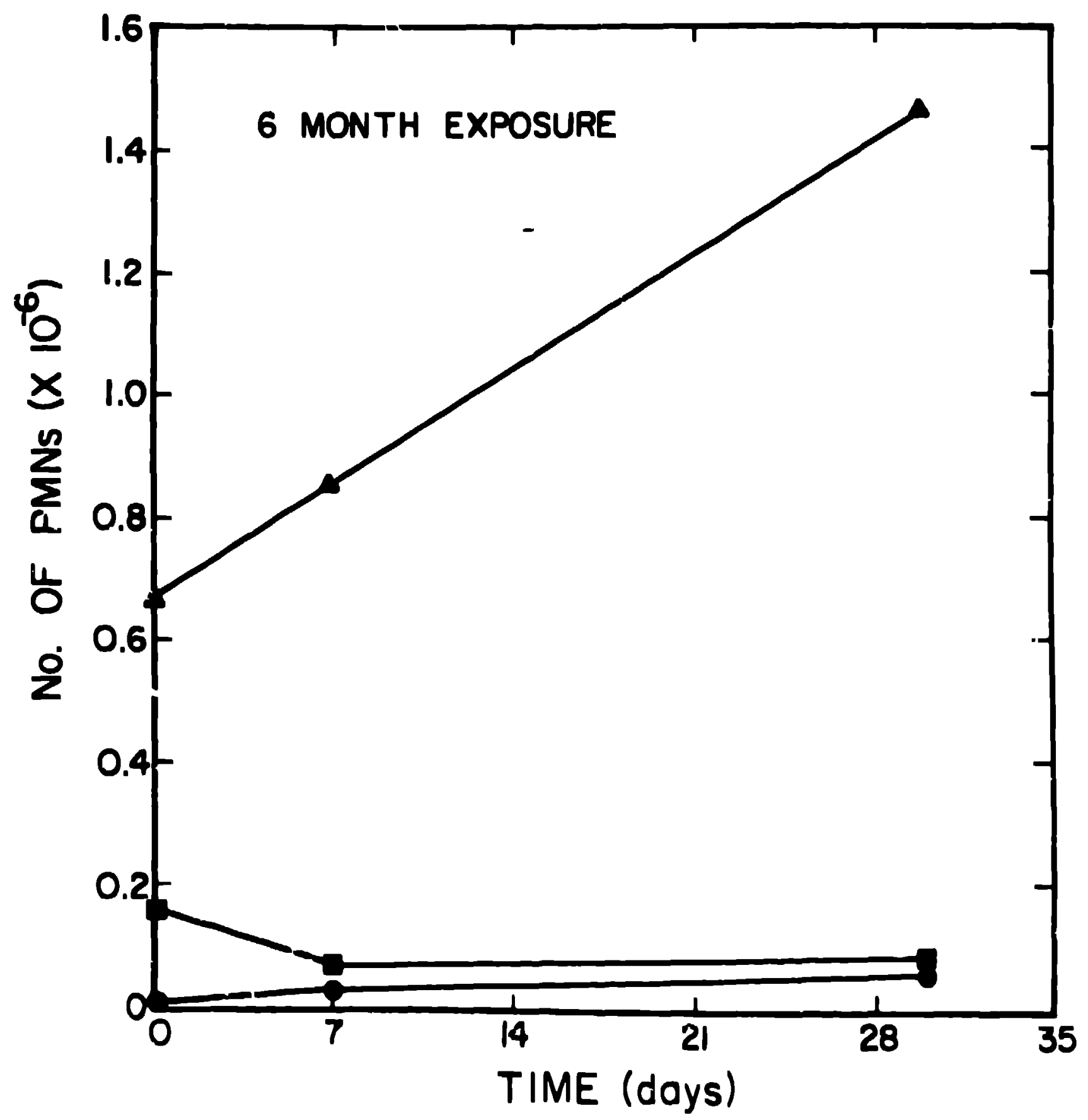


F1gure 5. Photomicrographs of sections of lungs from controls (A), shaleexposed (B), and quartz-exposed (C) unimals after 6 months of treatment. A pleural plaque (nidus of inflammatory cells, character1st1 = of 6- to 12-month quartz exposures) can be seen at the area Indicated by the arrow in (C). 
(A)

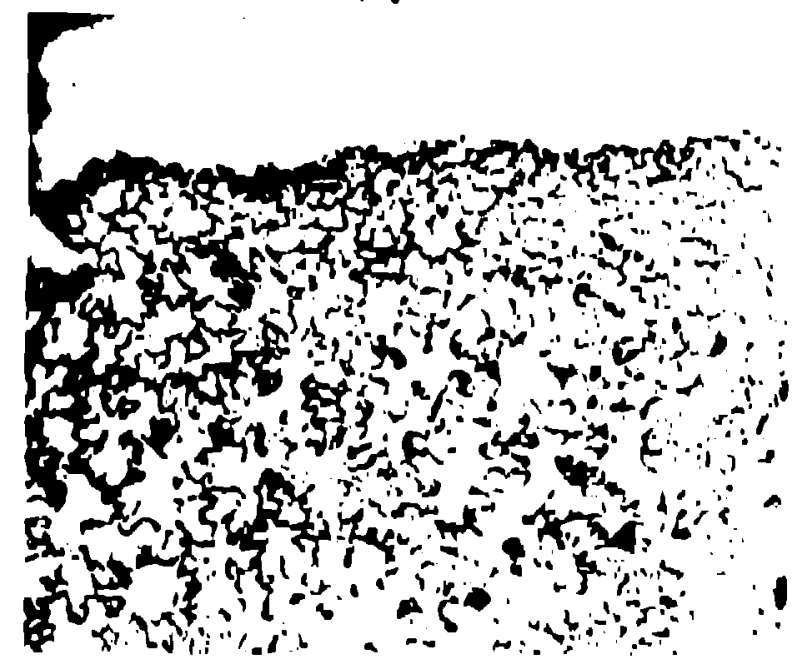

\section{(B)}

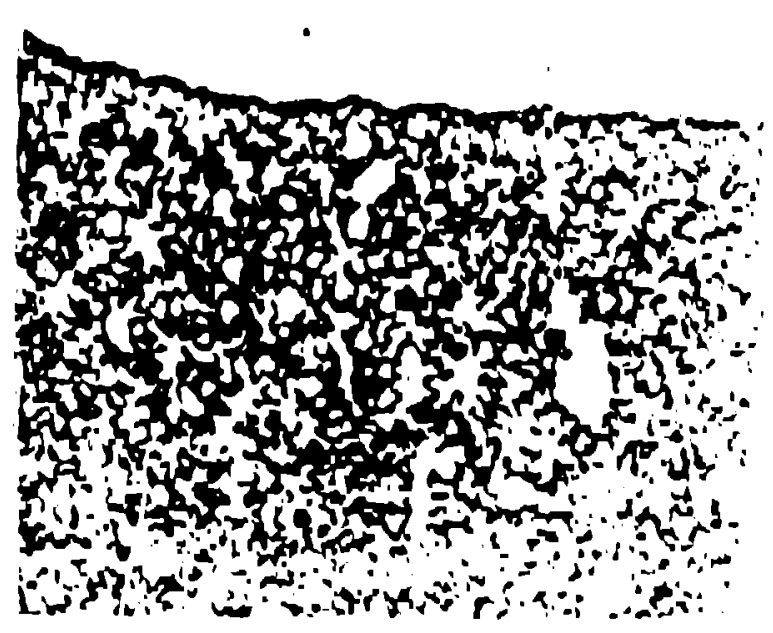

(c)

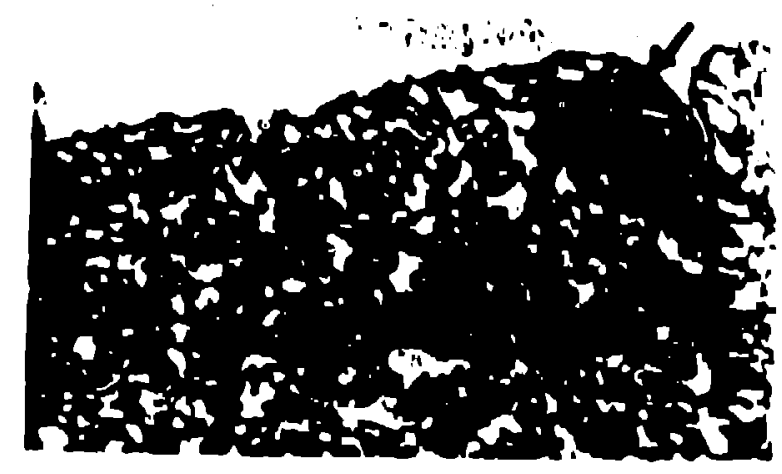


Flgure 6. Photomicrograph of a section of $1 \mathrm{ung}$ from a rat exposed to quartz for 12 months with a mature, well-organized pleural plaque. Multiple plaques at the pleural surface were observed in both gross and mlcroscopic specimens. 


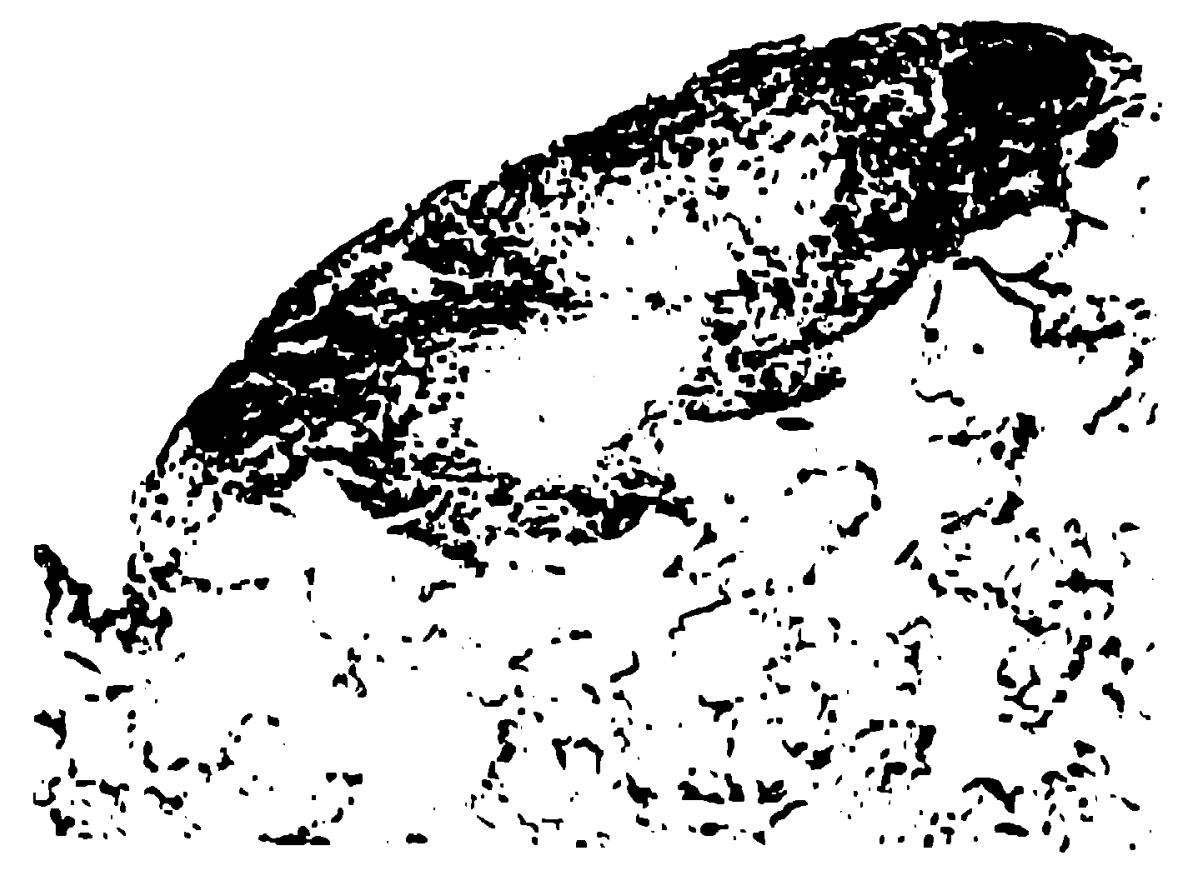


TABLF I. Totel cell yields and differentials 1 or treated and control animals after 1-, 7-, 6-, and 12-oonth exposures. Iotal ce:l yields Increased for ti.e que-tz-exposed enimals by 6 and 12 months as a result of Increases in lymphocytes ano PhNs.

\begin{tabular}{|c|c|c|c|c|c|c|}
\hline $\begin{array}{l}\text { Length of } \\
\text { Exposure }\end{array}$ & $\begin{array}{c}\text { Treatnent } \\
\text { Group }\end{array}$ & $\begin{array}{c}\text { Total } \\
\text { Cell Y leld }\end{array}$ & PAM & $\begin{array}{c}\text { Numbers of } \\
\text { Lym_hs }\end{array}$ & & PMN \\
\hline (nonths) & & $\left(\times 10^{6}\right)$ & & $\left(z 10^{6}\right)$ & & \\
\hline 1 & Cortcrol & $21 \pm 0.2$ & $1 . \bar{i} \pm 0.1$ & $0.3 \pm 0.1$ & & 0 \\
\hline 1 & Shale & $2.7 \pm 0.5$ & $2.0 \pm C .:$ & $0.5 \pm 0.5$ & 0.04 & \pm 0.4 \\
\hline 1 & Ouartz & $2.2 \pm 0.7$ & $1.5=0.1$ & $0.6 \pm 0.6$ & 0.02 & \pm 0.02 \\
\hline$\overline{3}$ & Control & $1.8 \pm 0.1$ & $1.6 \pm 0.1$ & $0.2 \div 0.02$ & & J \\
\hline 3 & Shale & $1.7 \pm 0.3$ & $1.5 \pm 0.3^{\circ}$ & $0.1 \pm 0.05$ & & 0 \\
\hline j & Quartz & $1.3 \pm 0.1$ & $0.9 \pm 0.1=$ & $0.3 \pm 0.1$ & $0.0 \overline{3}$ & $=0.0 s$ \\
\hline$:$ & Control & $1.5 \pm \bar{v} . \bar{s}$ & $1 . c \pm U .2$ & i. $1 \pm \bar{j} 1$ & 0.01 & \pm 0.02 \\
\hline$c$ & Shale & $1.3 \pm 0.5=$ & $1.0 \pm 0.4$ & $0.1 \pm 0.4$ & 0.10 & $=0.088$. \\
\hline$\epsilon$ & Quartz & $2.7 \pm 0.506$ & $1.5 \pm 0.3$ & $0.4 \pm 0.3^{\circ}$ & 0.67 & \pm 0.1900 \\
\hline 12 & Concrol & $1.5 \div 0.5$ & $1.2 \pm 0.5$ & $0.1 \pm 0.0 .1$ & $0.0_{3}$ & \pm 0.01 \\
\hline 12 & Snale & $1.5 \pm 0.10$ & $1.0 \pm 0.1$ & $0.2 \pm 0.05$ & 0.20 & \pm 0.111. \\
\hline 12 & Guartz & $2.9 \pm 1.200$ & $1.2+0.7$ & $0.7=0.300$ & $0.8 \mathrm{~s}$ & \pm 0.2300 \\
\hline
\end{tabular}

Value is significantly different from quartz value at the 958 confidence level by student's test.

- Value is significantly different from control at the 9hi confluence tevel by student's t test. 
TABLE II. Total cell yields and differentials for 6-, and 12-month exposures lollowing 7 or 30 days of recovery. Persistent increases in numbers of PMN and lymphocytes are evident for the quartz-exposed animals after s1x months, but only at 12 months of exposure for the shal $E-$ treoted animals.

\begin{tabular}{|c|c|c|c|c|c|}
\hline Time* & $\begin{array}{c}\text { Treatmen' } \\
\text { Group }\end{array}$ & $\begin{array}{c}\text { Total } \\
\text { Cell Yleld } \\
\end{array}$ & PAM & $\begin{array}{c}\text { Numbers of } \\
\text { Lymphs }\end{array}$ & PMY \\
\hline & & $\left(x 10^{6}\right)$ & & $\left(x 10^{6}\right)$ & \\
\hline $6 / 7$ & control & $1.6 \pm 0.2$ & $1.4 \pm 0.2$ & $0.12 \pm 0.33$ & $0.03 \pm 0.03$ \\
\hline $6 / 7$ & Shale & $1.4 \pm 0.3$ & $1.2 \pm 0.3$ & $0.10 \pm 0.04 \cdots$ & $0.07 \pm 0.03$ \\
\hline $6 / 7$ & Quarti & $2.1 \pm 0.6$ & $0.9 \pm 0.3 *$ & $0.24=0.104$ & $0.86 \pm 0.4 *$ \\
\hline $6 / 30$ & Control & $2.4 \pm 0.5$ & $3.2 \pm 0.2$ & $0.23 \pm 0.3$ & $0.06 \pm 0.2$ \\
\hline $6 / 30$ & Shale & $2.2 \pm 0.7$ & $1.7 \pm 0.6 \mathrm{dL}$ & $0.10 \pm 0.02$ & $0.09 \pm 0.02$ \\
\hline $6 / 30$ & Quartz & $5.7 \pm 1.400$ & $2.9 \pm 0.7$ & $1 . i 7 \pm 0.5 * 1$ & $1.47 \pm 0.6 \ldots$ \\
\hline $12 / 7$ & Control & $1.6 \pm 0.4$ & $1.3 \pm 0.4$ & $0.15 \pm 0.03$ & $0.04 \pm 0.02$ \\
\hline $12 / 7$ & Shrale & $2.4 \pm 2.0$ & $0.81 \pm 0.2$ & $0.15 \pm 0.07$ & $0.1 \pm 0.07 \cdots$ \\
\hline $12 / 7$ & Quartz & $3.6 \pm 0.6$ & $1.6 \pm 0.6$ & $0.67 \pm 0.4 \cdots 1$ & $1.11 \pm 0.201$ \\
\hline $12 / 30$ & Control & $1.8 \pm 0.5$ & $1.4 \pm 0.3$ & $0.13 \pm 0.10$ & $0.06 \pm 0.05$ \\
\hline $12 / 30$ & Shale & $3.7 \pm 1.4$ & $2.8 \pm 1.2 \cdots$ & $0.38 \pm 0.18 .5$ & $0.32 \pm 0.1385$ \\
\hline $12 / 30$ & Quertz & $5.9 \pm 1.3$ & $2.9 \pm 0.8 \cdots$ & $0.74 \pm 0.3=10$ & $2.1 \pm 0.6 \cdots$ \\
\hline
\end{tabular}

- Months or Exposure/Days or Recovery.

- Value ts sisniflcantly different from quartz value at the $95 \%$ confidence level by student's t test.

covalue is signiftoantly different from contrcl at the $95 \pi$ confldence level by student's t test. 